Nida Mauizdati ${ }^{1}$

\title{
KEBIJAKAN MERDEKA BELAJAR DALAM PERSPEKTIF SEKOLAHNYA MANUSIA DARI MUNIF CHATIB
}

\begin{abstract}
Abstrak
Seiring dengan semakin dewasanya negeri ini, pendidikan pun selalu berbenah ke arah yang lebih baik, beberapa waktu yang lalu, Mendikbud Nadiem Makarim menelurkan kebijakan baru bagi dunia pendidikan di Indonesia, yang disebutnya sebagai gebrakan merdeka belajar. Gebrakan ini menawarkan konsep pendidikan yang sangat ideal dimana guru maupun siswa dipandang sebagai subjek dalam proses pembelajaran dimana keduanya dapat saling bersinergi. Tulisan ini membahas komponen-komponen kebijakan merdeka belajar dan juga tujuan tujuan dibalik munculnya kebijakan ini. Selain itu, tulisan ini juga menyandingkan konsep merdeka belajar ini dengan konsep sekolahnya manusia yang lebih dahulu dikenal. Tulisan ini menunjukkan bahwa pendidikan di Indonesia sudah mengarah pada konsep pendidikan yang memanusiakan manusia. Siswa tidak lagi dipandang sebagai individu yang perkembangan belajarnya selama beberapa tahun hanya diukur dengan rangkaian-rangkaian tes terstandar yang tidak mengukur sampai ke tahap berpikir yang tinggi. Selain itu, pendidikan juga sudah beranjak dari sistem pengkastaan berdasarkan favorit atau tidak favoritnya lembaga pendidikan.
\end{abstract}

Kata Kunci: Pendidikan, Merdeka Belajar, Sekolahnya Manusia.

\begin{abstract}
As time goes, education is always improving to a better direction, some time ago, the Minister of Education and Culture Nadiem Makarim announced a new policy for the education in Indonesia, which he called "Merdeka Belajar". "Merdeka Belajar" offers an ideal educational concept where teachers and students are seen as subjects in the learning process where they can work together. This paper discusses the components of "Merdeka Belajar" as well as the objectives behind the emergence of this policy. In addition, this paper also compares the concept of "Merdeka Belajar" with the concept of "Sekolahnya Manusia" which was previously known. This paper shows that education in Indonesia has led to the concept of humanizing education. Students are no longer seen as individuals whose learning progress over several years is only measured by a series of standardized tests that do not measure up to a high thinking stage. In addition, education has also moved away from a classification system based on the favorites or not of educational institutions.
\end{abstract}

Keywords: Education, Merdeka Belajar, Sekolahnya Manusia.

\footnotetext{
${ }^{1}$ Pendidikan Guru Madrasah Ibtidaiyah, Sekolah Tinggi Ilmu Al-Qur'an AMuntai

Alamat email: nida.m39@gmail.com
} 


\section{PENDAHULUAN}

Pembahasan tentang kurikulum selalu menarik untuk dikaji. Karena perkembangannya berkaitan/berdampak pada perkembangan generasi-generasi muda negeri ini yang menjadi harapan kita semua, bangsa ini. Pada akhir tahun 2019 yang lalu, menteri pendidikan dan kebudayaan terpilih, Nadiem Makarim, mencetuskan kebijakan baru dalam dunia pendidikan yang disebutnya dengan kebijakan merdeka belajar. Kebijakan ini dibuat bukan tanpa alasan. Dilatatarbelakangi hasil penelitian Programme for International Student Assesment (PISA)pada tahun 2019 menunjukkan bahwa hasil penilaian pada peserta didik Indonesia hanya menduduki posisi keenam dari bawah. Adapun untuk bidang matematika dan literasi, Indonesia menduduki posisi ke-74 dari 79 Negara. Beranjak dari fakta inilah gebrakan ini dicetuskan oleh Nadiem (Mustaghfiroh, 2020).

Kebijakan ini berisi empat pokok bahasan, yaitu tentang penghapusan ujian nasional, penyelenggaraan ujian sekolah berstandar nasional yang pelaksanaannya diserahkan kepada sekolah, penyederhanaan format rencana pelaksanaan pembelajaran (RPP), dan tentang sistem zonasi penerimaan siswa baru (PSB). Kebijakan ini membawa cita-cita besar yang ingin dicapai oleh Kementerian Pendidikan dan Kebudayaan dengan adanya kebijakan merdeka belajar ini adalah terbentuknya kultur lembaga pendidikan yang otonom, tidak birokratis, serta semakin berkembangnya inovasi sistem pembelajaran (J. Syahfitri, 2020, p. 4).

Selain itu, konsep merdeka belajar memberikan tawaran dalam penataan ulang sistem pendidikan nasional. Penataan ulang sistem pendidikan ini dilakukan dalam rangka menyambut perubahan-perubahan bangsa sebagai dampak dari perkembangan zaman. Dengan cara, mengembalikan pendidikan pada hakikatnya dimana pendidikan adalah proses memanusiakan manusia. Dalam konsep merdeka belajar, guru bukan dijadikan sumber kebenaran oleh siswa, namun guru dan siswa berkolaborasi penggerak dan mencari kebenaran, karena guru dan siswa, keduanya adalah subjek pendidikan itu sendiri (Yamin \& Syahrir, 2020).

Di sisi lain, ada satu konsep pendidikan/lembaga pendidikan yang digaungkan Munif Chatib tentang bagaimana semestinya sekolah memandang dan memperlakukan siswanya. Munif pun berpendapat bahwa pembelajaran selama ini cenderung memandang siswa sebagai individu-individu yang sama sehingga mendapat perlakuan dan standar kecerdasan yang sama. Padahal setiap individu ini memiliki gaya belajar dan jenis kecerdasan yang sama. Munif menawarkan sebuah solusi bagi dunia pendidikan, yakni dengan sekolah berbasis kecerdasan majemuk atau Multiple intelligences. Konsep sekolah yang seperti ini, pertama-tama diterapkan di sekolah binaannya, yaitu SMP YIMI Full Day School yang semula bernama SMP Malik Ibrahim Gresik. Sekolah tersebut pada awalnya berada di kondisi memprihatinkan karena minim kepercayaan masyarakat terhadap lembaga pendidikan. Selanjutnya sekolah berbenah secara besar-besaran dengan merombak sistemnya menjadi sekolah yang berbasis multiple intelligences system.

Sekolah ini, dalam pembelajarannya mempertimbangkan jenis kecerdasan dan gaya belajar siswa. semua siswa dipandang sebagai makhluk yang sama-sama memiliki potensi/kecerdasan, meskipun di bidang ataupun ranah yang berbeda. Segala detail mengenai konsep sekolah ini dijelaskannya di buku yang berjudul sekolahnya manusia. Buku ini juga berisi banyak kisah inspiratif, dimana siswa yang pada awalnya dianggap gagal, nakal, dan tidak memiliki harapan, ternyata dapat menemukan kondisi terbaiknya menjadi individu yang membanggakan di bidangnya masing-masing.

Melihat pada konsep sekolah dengan multiple intelligences system tersebut dan juga munculnya kebijakan merdeka belajar yang menjadi gebrakan besar oleh kemendikbud, yang 
kalau ditelaah lebih lanjut gebrakan merdeka belajar ini mencita-citakan system pendidikan yang sangat berpusat pada siswa dan yang lebih memanusiakan manusia. Dalam hal ini penulis tertarik untuk menelaah lebih lanjut kesamaan sudut pandang keduanya terhadap cita-cita pendidikan nasional.

\section{METODE}

Penelitian ini adalah penelitian kepustakaan (library research). Penelitian kepustakaan ini didefinisikan sebagai penelitian yang menjadikan sumber-sumber tertulis sebagai sumber datanya (Rahmadi, 2011, p. 13). Penelitian kepustakaan memaksimalkan pemanfaatan fungsi sumber-sumber perpustakaan untuk memperoleh data penelitian. Lebih lanjut dapat dipahami bahwa penelitian pustaka membatasi kegiatannya hanya pada bahan-bahan koleksi perpustakaan saja tanpa memerlukan penelitian lapangan (Zed, 2008, p. 1-2). Amir Hamzah menjelaskan bahwa penelitian kepustakaan ialah penelitian kualitatif yang bekerja pada tataran analitik serta bersifat perspective emic, yang berarti bahwa penelitian ini tidak memperoleh data yang berdasarkan pada perspektif peneliti, tetapi berdasarkan fakta-fakta konseptual ataupun faktafakta teoritis (Hamzah, 2020, p. 9). Adapun penelitian ini dilakukan dengan mengkaji data-data mengenai kebijakan merdeka belajar dari penjelasan Kemendikbud tentang empat pokok kebijakan merdeka belajar yang dikeluarkan pada tanggal 11 Desember 2019. Data tersebut kemudian dibandingkan dan ditelaah relevansi ataupun perbedaannya dengan konsep sekolahnya manusia yang dijabarkan Munif Chatib dalam bukunya.

\section{HASIL DAN PEMBAHASAN}

\section{Kebijakan Merdeka Belajar}

Kebijakan tentang "merdeka belajar" ini dijelaskan oleh Kemdikbud pada tanggal 11 Desember 2019 pada edarannya yang berisi penjelasan mengenai empat pokok kebijakan merdeka belajar ini, yaitu:

1. Ujian Sekolah Berstandar Nasional (USBN), pelaksanaannya digantikan dengan penilaian (asesmen) yang kebijakan pelaksanaannya diserahkan kepada pihak sekolah. Asesmen ini diselenggrakan untuk menilai kemampuan/kompetensi siswa dalam bentuk tes tertulis maupun bentuk penilaian lainnya yang bersifat lebih komprehensif, seperti penugasan atau penilaian portofolio.

2. Ujian Nasional (UN), ditiadakan. Peran UN kemudian digantikan dengan Asesmen Kompetensi Minimum dan Survei karakter. Penilaiannya meliputi aspek literasi, numerasi, dan survei karakter. Literasi disini tidak terbatas pada kemampuan membaca, namun secara luas yaitu kemampuan bernalar/memahami bacaan dan menggunakan bahasa. Adapun literasi, yaitu menilai kemampuan siswa dalam memahami dan menggunakan konsep matematika dalam kehidupan sehari-hari. Sementara survei karakter untuk mengetahui penerapan siswa terhadap nilai-nilai seorang individu pembelajar, nilai gotong royong, kebhinnekaan dan pancasila.

3. Penyederhanaan format Rencana Pelaksanaan Pembelajaran (RPP). Dalam hal ini guru diharapkan dapat secara lebih bebas memilih, membuat, serta menggunakan dan mengembangkan format RPP ini. Jika pada Kurikulum 2013 terdapat banyak komponen RPP hingga dapat mencapai 20 lembar, maka di RPP merdeka belajar ini, RPP cukup memuat 3 komponen inti yaitu tujuan, kegiatan pembelajaran, dan penilaian. Sementara 
komponen lain dapat dipilih secara mandiri. Penyederhanaan ini bertujuan agar guru memiliki lebih banyak waktu sehingga dapat mempersiapkan dan mengevaluasi proses pembelajaran itu sendiri.

4. Sistem zonasi Penerimaan Peserta Didik Baru (PPDB) lebih fleksibel. Dalam kebijakan ini, Kemendikbud memberikan fleksibilitas kepada daerah untuk mengakomodir ketimpangan akses dan kualitas pendidikan di berbagai daerah dengan pembagian sistem zonasi yaitu $50 \%$ jalur zonasi, $15 \%$ jalur afirmasi, $5 \%$ jalur perpindahan, sisanya jalur prestasi yang disesuaikan dengan kondisi daerah. Dalam hal ini daerah berwenang melakukan proporsi final dan menetapkan wilayah zonasi.(Pendidikan, 2019)

\section{Konsep Sekolahnya Manusia}

Konsep "sekolahnya manusia" dicetuskan oleh Munif Chatib terutama dalam bukunya yang berjudul "Sekolahnya Manusia: Sekolah Berbasis Multiple Intelligences di Indonesia". Sesuai judul bukunya, yang dimaksud dengan sekolahnya manusia menurut Munif Chatib ini ialah sekolah yang berbasis pada konsep multiple intelligences atau kecerdasan majemuk, dimana sekolah adalah tempat dimana semua jenis kecerdasan siswa dihargai (Chatib, 2012, p. xxi). Menurut Munif kecerdasan seseorang tidak dapat dibatasi hanya pada indikator yang ada dalam tes formal pada umumnya. Karena kecerdasan seseorang itu tidak statis, namun bersifat dinamis/selalu berkembang. Menurut Gardner sebagaimana dikutif Munif, kecerdasan dapat dilihat dari kebiasaan seseorang. Sementara kebiasaan adalah perilaku yang berulang. Sehingga tes kecerdasan yang dilakukan saat ini, hanya menilai kecerdasan seseorang itu pada waktu tersebut, bukan pada waktu sebulan, setahun, atau bahkan sepuluh tahun kemudian. Kecerdasan seseorang berasal/bersumber dari kebiasaan seseorang yang mempunyai nilai kreativitas dan kemampuan/kebiasaan seseorang dalam menyikapi dan menyelesaikan masalah (problem solving)(Chatib, 2012, p. 71).

Menurut konsep sekolah ini, sekolah unggul adalah sekolah yang berfokus pada kualitas proses pembelajaran, bukan berfokus pada input siswanya. Kualitas proses pembelajarannya ini tentunya bergantung pada kualitas para pengajar atau gurunya. Guru yang berkualitas inilah yang berperan sebagai "agen pengubah" siswanya (Chatib, 2012, p. 93). Inilah yang disebut Munif bahwa sekolah unggul ialah sekolah yang menekankan pada the best process, bukan the best input. Hal utama yang harus selalu diketahui oleh pendidik dalam menentukan proses pembelajaran adalah perbedaan individu siswa. Meskipun pada praktiknya, sistem pendidikan kita perbedaan individu siswa ini kerap kali menjadi masalah. Hal ini dikarenakan sistem pendidikan yang cenderung menyamaratakan standar kecerdasan antar siswa. Di mana kecerdasan siswa masih diukur dengan parameter yang sama yaitu aspek kognitif saja (Chatib, 2012, p. 12).

Pada konsep Sekolahnya Manusia ini, yang perlu ditekankan adalah penghargaan dan penerimaan bahwa setiap siswa memiliki jenis kecerdasan yang berbeda. Sehingga guru memandang bahwa setiap anak pasti memiliki minimal satu kelebihan. Disini lah konsep multiple intelligences ditekankan. Selain itu, proses penerimaan siswa baru pada sekolah ini juga tidak mengenal sistem seleksi dengan tes-tes formal. Yang dilakukan pada penerimaan siswa baru adalah menerima siswa yang memang lebih awal mendaftar sebelum kuota siswa terpenuhi. Selanjutnya, siswa yang diterima tadi dikenali melalui Multiple Intelligences Research (MIR). MIR ini bertujuan untuk mengetahui kecenderungan jenis kecerdasan yang paling menonjol di diri siswa. hasil dari MIR ini pula yang kemudian menjadi dasar bagi sekolah dan guru dalam mengembangkan proses pembelajaran. Jadi, MIR ini bukan digunakan 
untuk seleksi, namun untuk menjadi bahan pertimbangan yang tepat tentang treatment yang akan diterapkan pada siswa dalam pembelajaran (Chatib, 2012, pp. 92-95). Penerapan multiple intelligences dalam pembelajaran ini dapat diartikan sebagai penerapan strategi pembelajaran, dimana terdapat rangkaian aktivitas belajar yang merujuk pada indikator pencapaian hasil belajar yang sudah ditentukan dalam kurikulum (Chatib, 2012, p. 109).

\section{Kebijakan Merdeka Belajar Perspektif Konsep Sekolahnya Manusia}

\section{Ujian Sekolah Berstandar Nasional (USBN)}

Dalam hal ini, dijelaskan bahwa pelaksanaan USBN diserahkan kepada pihak sekolah untuk penyelenggarannnya. Bentuk ujian yang dilakukan dapat berupa tes tertulis atau bentuk penilaian lain seperti portofolio, penugasan, karya tulis, dan sebagainya. Kemendikbud menyebutkan pengembalian USBN kepada sekolah ini sebagai bentuk pengembalian ujian itu sendiri kepada esensinya. Dimana ujian sekolah semestinya memang dilaksanakan guru dan sekolah. Karena guru di sekolah lah yang paling tahu bagaimana perkembangan peserta didik selama di sekolah (Pendidikan, 2019). Adapun dari segi bentuk ujian, guru dapat menggunakan berbagai macam bentuk penilaian, bisa berupa tes tertulis, bisa juga penugasan, portofolio siswa, dan project kolaboratif. Waktu pelaksanaannya pun tidak mesti harus di akhir tahun ajaran. Tetapi tergantung pada kompetensi yang diukur dan instrument asesmen yang digunakan.

Dengan demikian, dapat dilihat dari segi format penilaian, kebijakan merdeka belajar ini menghendaki alat tes yang tidak hanya berfokus pada kemampuan kognitif, tetapi dilakukan secara komprehensif. Hal ini juga senada dengan penilaian yang ditawarkan dalam buku sekolahnya manusia. Bahwa penilaian hasil belajar, tidak bisa hanya diukur melalui kognitif saja. Dalam konsep sekolahnya manusia penilaian dilakukan dengan penilaian autentik. Penilaian autentik diartikan sebagai penilaian yang memperhatikan keseimbangan antara penilaian di aspek sikap, pengetahuan, maupun keterampilan (Kunandar, 2014, p. 39). Munif menjelaskan bahwa penilaian ini berparadigma: menekankan pada kompetensi yang diajarkan; membantu siswa yang lemah untuk berkembang; penilaian kompetensi ini cenderung dapat membangun semangat kerjasama; menitikberatkan pada ketiga ranah yaitu kognitif, afektif, dan psoikomotorik; serta dilakukan dengan teknik tes dan non tes. Penilaian yang dilakukan adalah penilaian berbasis proses, dimana penilaian dilakukan saat proses pembelajaran itu berlangsung. Selain itu juga menganut konsep ipsative yaitu perkembangan hasil belajar siswa bukan dibandingkan dengan siswa lain, tetapi dibandingkan atau diukur dengan perkembangan individu itu sendiri sebelum dan sesudah pembelajaran. Bentuk penilaian yang dapat dilakukan diantaranya yaitu tes tertulis, tes lisan, tes identifikasi, simulasi, work-sample, project, juga portofolio (Chatib, 2012, pp. 155-171). Dari pemaparan di atas, terlihat bahwa keduanya dalam hal penilaian, berparadigma sama, bahwa hasil belajar tidak hnya diukur melalui tes kognitif saja, namun juga mempertimbangkan aspek perkembangan/kompetensi yang lebih komprehensif.

\section{Penghapusan Ujian Nasional}

Dalam kebijakan ini, Ujian Nasional (UN) rencananya dihapuskan terhitung sejak tahun 2021. Namun pandemic covid-19 mempercepat pembehentian pelaksanaan UN di tahun 2020. Pelaksanaan UN akan digantikan dengan asesmen kecakapan minimum di aspek Literasi, Numerasi, serta dengan survei karakter. Beberapa alasan kenapa UN dianggap lebih baik diakhir diantaranya: pertama, UN sejauh ini kebanyakan berisi butir-butir yang mengukur kompetensi berpikir tingkat rendah. Sementar tujuan pendidikan mengharapkan dapat mengembangkan 
kemampuan berpikir tingkat tinggi disertai kompetensi lain yang relevan terhadap perkembangan zaman. Kedua, UN membuat guru kurang tergerak untuk menggunakan metode pengajaran yang efektif untuk mengembangakan kemampuan berpikit ringkat tinggi siswa. sehingga asesmen pengganti UN dirancang untuk memberikan dorongan untuk pelaksanaan pembelajaran yang lebih inovatif dan berpusat pada pengembangan kemampuan menalar, bukan hanya menghafal. Ketiga, UN juga dianggap bukan alat yang dapat berperan optimal untuk memperbaiki mutu pendidikan nasional (Pendidikan, 2019).

Adapun dalam konsep sekolahnya manusia, Munif Chatib juga menyiratkan pandangan yang sama terhadap UN. Dimana menurutnya UN pada dasarnya bertentangan dengan isi kurikulum pendidikan yang berlaku, penerapan kurikulum pendidikan yang tidak sejalan atau bersesuaian dengan evaluasi akhirnya (Chatib, 2012, p. 86). Dengan demikian, dapat kita lihat bahwa UN dianggap tidak sepenuhnya bisa merepresentasikan hasil belajar siswa selama berada dalam satuan pendidikan.

\section{Penyederhanaan Format RPP}

Pada format RPP K-13, terdapat banyak sekali komponen yang harus termuat dalam RPP. Satu buah RPP bisa menghabiskan/mencapai 20 halaman. Hal ini selain dianggap kurang efisien, juga dianggap memberatkan guru karena harus membuat RPP yang banyak itu di samping tugas mengajar yang juga banyak. Sehingga pada era merdeka belajar ini, guru dibebaskan untuk membuat, memilih, dan mengembangan RPP, selama sesuai dengan prinsip efisien, efektif, dan berorientasi pada murid. Efisien artinya penulisan RPP tidak menghabiskan bnyak waktu dan tenaga. Efektif artinya penulisan RPP bertujuan untuk mengarahkan pembelajaran agar dapat mencapai tujuan pembelajaran. Serta Berorientasi pada siswa artinya guru mempertimbangkan kesiapan, ketertarikan, dan kebutuhan belajar siswa dalam membuat RPP ini. Dengan demikian, pembuatan RPP sepenuhnya diserahkan kepada guru untuk berkreasi dan mengembangkan RPP nya. Adapun komponen yang harus termuat dalam RPP adalah 3 komponen inti, yaitu tujuan pembelajaran, langkah-langkah pembelajaran, dan penilaian/asesmen pembelajaran (Pendidikan, 2019). Adapun dalam konsep sekolah berbasis multiple intelligences, Rencana Pelaksanaan Pembelajaran (RPP) dikenal dengan Lesson Plan. Munif sangat menekankan pentingnya lesson plan ini dibuat oleh guru sebelum pembelajaran. Menurutnya kualitas pembelajaran yang dilakukan guru yang diawali dengan membuat lesson plan dan yang tidak, akan berbeda karena yang membuat lesson plan lebih memiliki kesiapan dalam mengajar. Untuk format lesson plan ini, Munif memberikan beberapa kerangka lesson plan menurut para ahli di bukunya yang berjudul gurunya manusia. Selanjutnya struktur lesson plan yang dirumuskan Munif memiliki 3 bagian yaitu: Header, Content, dan Footer. Header berisi identitas lesson plan seperti mata pelajaran dan nama guru, serta silabus berisi indicator dan tujuan pembelajaran. Content berisi kegiatan mengajar meliputi pendahuluan, kegiatan inti, dan penutup, serta berisi administrasi mengajar yaitu tentang media dan sumber belajar. Footer berisi instrumen penilaian dan komentar guru (Chatib, 2018, p. 206).

\section{Kebijakan Penerimaan Peserta Didik Baru (PPDB)}

Dalam konteks PPDB ini, kemendikbud membuat perubahan dalam sistem zonasi. Dari yang sebelumnya PPDB jalur zonasi ini memiliki porsi $80 \%$ kuota PPDB menjadi hanya $50 \%$. Selain itu, ketentuan lainnya terkait pembagian zonasi ini juga diserhkan kepada daerah untuk lebih mengkaji kemudian menetapkan pembagian yang paling tepat untuk daerahnya. Sistem zonasi ini perlu adanya sebagai upaya menghilangkan kesenjangan antara sekolah favorit dan non-favorit. Hal ini menunjukkan bahwa kebijakan ini memiliki cita-cita yang sama dengan penerimaan siswa baru pada sekolah berbasis multiple intelligences. Dimana pada penerimaan 
siswa baru yang diterima adalah yang mendaftar pada saat kuota siswa baru belum penuh. Sehingga siswa yang terjaring tidak terkumpul berdasarkan kemampuan akademik. Hal inilah yang kemudian menjadi penerapan bahwa lembaga pendidikan semestinya menekankan pada the best process bukan the best input.

\section{SIMPULAN}

Berdasarkan pemaparan di atas, kita dapat lihat bahwa pendidikan di Indonesia sudah mengarah pada konsep pendidikan yang memanusiakan manusia. Siswa tidak lagi dipandang sebagai individu yang perkembangan belajarnya selama beberapa tahun hanya diukur dengan rangkaian-rangkaian tes terstandar yang tidak mengukur sampai ke tahap berpikir yang tinggi. Selain itu, pendidikan juga sudah beranjak dari system pengkastaan berdasarkan favorit atau tidak favoritnya lembaga pendidikan. Semua anak berhak sekolah tanpa memandang aspek taraf hidup seperti itu, karena semua anak dipandang sama yaitu individu yang akan diarahkan guru untuk dapat berkembang optimal menuju kedewasaan.

\section{DAFTAR PUSTAKA}

Chatib, M. (2012). Sekolahnya Manusia: Sekolah Berbasis Multiple Intelligences di Indonesia. Kaifa.

Chatib, M. (2018). Gurunya Manusia: Menjadikan Semua Anak Istimewa dan Semua Anak Juara. KAIFA.

Hamzah, A. (2020). Metode Penelitian Kepustakaan (Library Research) Kajian Filosofis, Aplikasi, Proses, dan Hasil Penelitian. Literasi Nusantara.

J. Syahfitri, H. F. (2020). P-issn 2620-861x e-issn 2620-8628. 1-11.

Kunandar. (2014). Penilaian Autentik (Penilaian Hasil Belajar Peserta Didik Berdasarkan Kurikulum 2013) Suatu Pendekatan Praktik. Rajawali Press.

Mustaghfiroh, S. (2020). Konsep "Merdeka Belajar" Perspektif Aliran Progresivisme John Dewey. Jurnal Studi Guru Dan Pembelajaran, 3(1 SE-Articles), 141-147. https://e-journal.my.id/jsgp/article/view/248

Pendidikan, M. (2019). Merdeka Belajar. Kementerian Pendidikan Dan Kebudayaan, 121.

Rahmadi. (2011). Pengantar Metodologi Penelitian. Antasari Press.

Zed, M. (2008). Metode Penelitian Kepustakaan. Yayasan Obor Indonesia.

Yamin, M., \& Syahrir, S. (2020). Pembangunan Pendidikan Merdeka Belajar (Telaah Metode Pembelajaran). Jurnal Ilmiah Mandala Education, 6(1), 126-136. https://doi.org/10.36312/jime.v6i1.1121 